\title{
Raptores Banded in 1964
}

\author{
by C. Stuart Houston, Saskatoon
}

The success of an owl bander depends not so much on his own efforts as the help he receives from others. I would like to express my appreciation to all those who located nests in 1964, and ask for even more support in the coming year. Most of the owl nests reported this year were in response to a request in Doug Gilroy's nature column, "Prairie Wildlife," in the Western Producer. (For information on my previous raptor banding operations see Blue Jay, 17:106, and 18:105-110.)

We travelled over 1,000 miles on the long weekend beginning Friday evening, May 15, accompanied by Bill Horseman. The first loop included stops at Dundurn, Allan, Ruthilda, Denholm, Ruddell and Leroy. We arrived in Yorkton just after midnight Saturday and left again at 3:30 a.m. Sunday with Larry Morgotch added to the crew. We visited owl nests at Gorlitz, Springside, Theodore, Tuffnell, Tonkin, Rokeby and Saltcoats. I just had time to get over to Regina to catch the T.C.A. plane to Vancouver (necessitated by sudden illness in the family). Next morning, on her return to Saskatoon, Mary banded Great Horned Owls in four additional nests, with the help of her sister, Margaret, at Dilke, and Lawrence Beckie at Bladworth. A total of 53 Great Horned Owls had been banded that weekend in 26 nests; later we added 16 Great Horned Owls in nine other nests.

Nesting success was almost as good as in 1960. Of the 35 Great Horned Owl nests where young were banded, 10 raised three young, 17 raised two young and eight raised one young. Unfortunately, three young were taken from two nests before our final visit, so only 69 instead of the potential 72 birds were banded.

Of the nine nests visited on or after May 20, only one contained food (a young rabbit). Of 26 nests visited on the "long weekend," six contained no food, and two nests were not inspected closely. The remaining 18 nests contained a total of eight rats, five rabbits, five pocket gophers, three teal, two mallard, two pintail, two meadow mice (Microtus), one muskrat, one sora and one coot. Pocket gophers seemed a less dominant food item than in 1960, and extra uneaten food supply in nests were less plentiful this year.

The Great Horned Owl nests varied in height from 14 to 45 feet above the ground, with an average of $271 / 2$ feet. I now carry three 10-foot sections of aluminum ladder on top of my car, and can get to almost any prairie owl nest even if I don't have Bill Horseman with me!

Larry Morgotch found five of the Great Horned Owl nests; Bill Horseman, four; J. R. Harcourt of Leroy, three; Jim Slimmon, two; Gwilym and Trevor Jones of Findlater, two; Marvin Schmidt, Frank Roy, Ed Falk, Jim Agar, W. J. Bruchs, .Mrs. T. Turner and Fred Sage of Saskatoon each found one, as did Harry Parker of Allan, Marshall Evans of Ruddell, Murray M. Bilokreli of Theodore, Irving and Gordon Pearce of Tonkin, Dave Baines of Crescent Lake, Miss Mary MacNutt of Saltcoats, P. Lawrence Beckie of Bladworth, Lloyd and Kelvin Barry of Young, Wes Schmidt and Rollie Woods of Ruddell, and Fred Lawrence of Colonsay.

Long-eared Owls required our attention in June. Joe and Marvin Schmidt found three nests just west of Saskatoon. At the first nest on June 8 , the adult female owl would not leave the nest, so received an aluminum band on her leg in exchange for a series of claw marks on the back of my right hand. Her five young were also banded. The most successful nest was the one found east of the city by Jim Slimmon, with six young banded on June 17. Brian Boechler of Allan located one nest and Marshall Evans of Ruddell found four nests on his farm. The season's total for Longeared Owls was 28 young banded in eight nests.

Short-eared Owls were also plentiful in the Ruddell district, where a community effort was captained by Wes Schmidt and Marshall Evans, with help from Warren Ballsrud and Ernie Vogel. A number of the nests under observation were destroyed by farming operations or deserted, but young were banded in six nests. Jim and. John Dempsey located another 


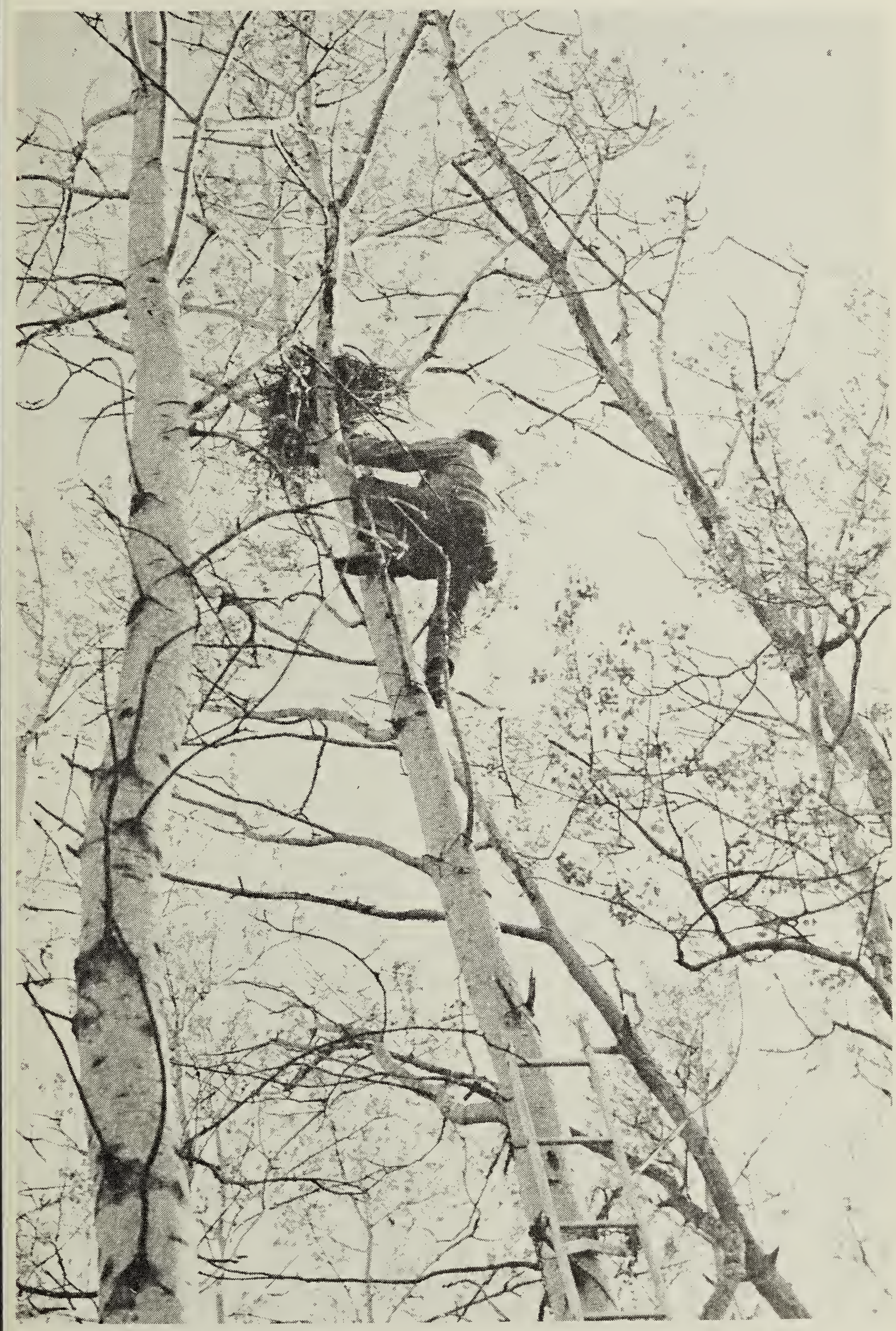

Phato by Hans S. Dommasch

Bill Horseman nearing Great Horned Owl nest, Dundurn, May 15, 1964 
nest at Young, making a total of 15 young banded in seven nests.

The banding of four young Golden Eagles in three nests on the South Saskatchewan cliffs brought my fouryear total to 14 , and was again one of the highlights of the year. One nest was located by Alfred Jones of Beechy during the Saskatchewan Natural History Society summer meeting on June 6. The next day, Stanley Peters flew Bob Taylor west to check on and confirm occupancy of a nest used in 1961. We banded the two young in this nest on the roundabout journey home, accompanied by Taylor, Nero and his sons, and the Chandlers. Another nest, followed by Dave Santy all spring, was washed down the cliff during a May storm; the second nest under his observation, which had two eggs on April 9, held only one eaglet on June 21.

I also banded four young Red-tailed Hawks in two nests; eight Swainson's Hawks in three nests; nine Marsh Hawks in three nests; eight Pigeon Hawks in two nests; four Sparrow Hawks and three Saw-whet Owls in single nests.

I hope to band another 60 or more Great Horned Owls in 1965, for I should eventually band over one thousand to obtain statistically significant results. They yield a good percentage of recoveries (36 from the first 303 banded, or $12 \%$ ), including one from Minnesota, two from North Dakota, and six from Manitoba. I wish to learn more about the wanderings of this "non-migratory" species.

Readers must be warned never to climb up to an owl's nest when they are alone or in poor light; in fact, it is best to study their habits from the ground! I know of three people, including one bander, who have lost the sight of one eye from the sharp talons of a Great Horned Owl. (And refer to Blue Jay, 18:18-19, 1960.)

Any school (or person) in Saskatchewan finding five active Great Horned Owl nests whose young I band, will receive a Peterson's Field Guide to the Western Birds, or other guide in this series. The best area for owl nests is the "parkland" area through North Battleford, Humboldt and Yorkton. I can likely visit all single nests in these areas, but would prefer three or more nests per district elsewhere in the province to make the trip worthwhile. Students finding single nests will receive a year's subscription to the Blue Jay when the young owls are banded.

Great Horned Owls begin nesting in late February or early March and I have known them to incubate eggs successfully in twenty-below-zero weather. The young owls are large enough to band by the second week in May, and often leave their nest about May 20. When a nest is located, please write to me at 863 University Drive, Saskatoon-before May 1 if possible. If necessary, phone collect to 244-0742.

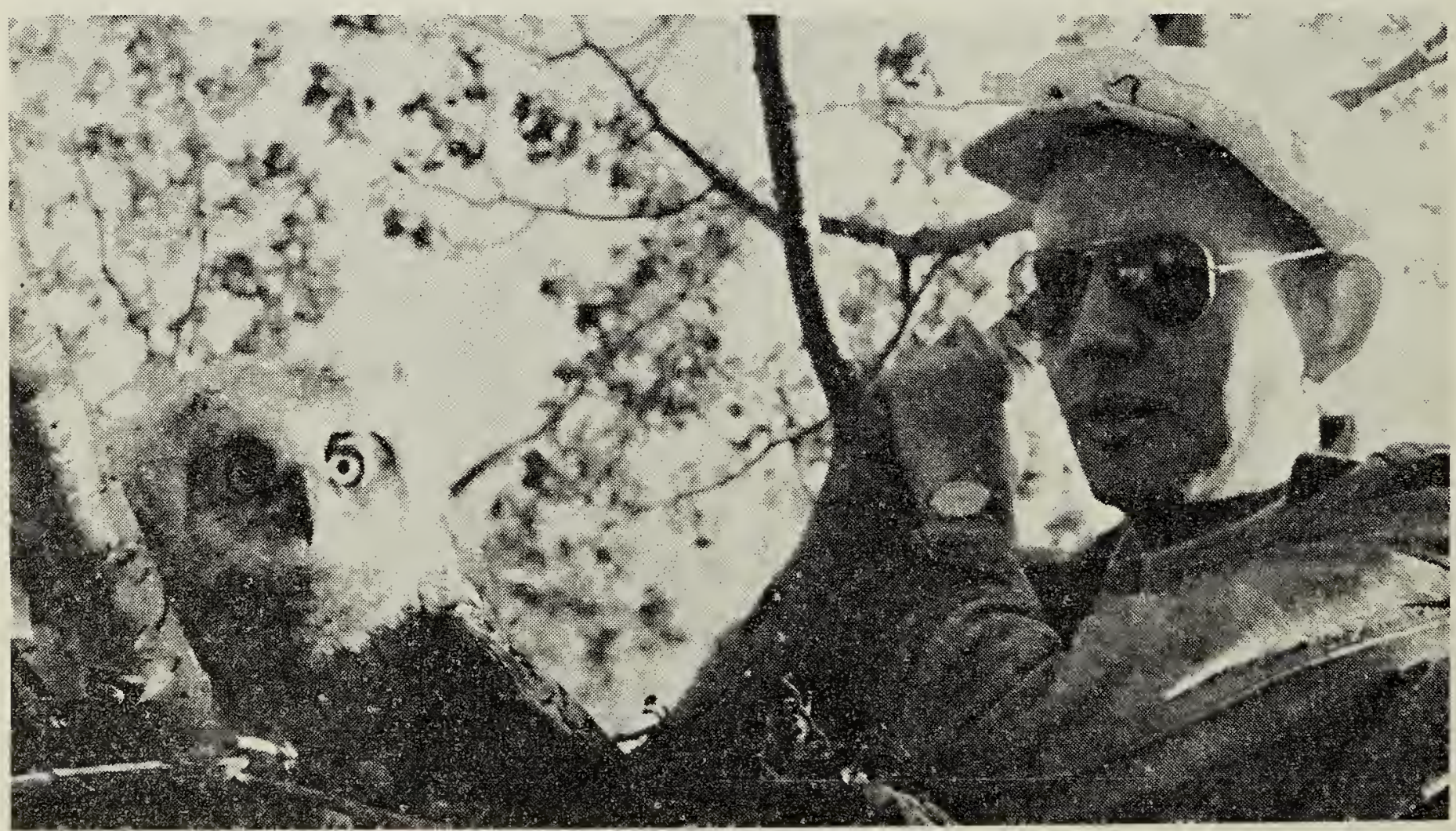

Young Great Horned Owl and author. Nest located by Harry Parker, Allan, May 15, 1964. Photo by Hans S. Dommasch 